\title{
Private Archives: Relationship with the State Archives
}

\author{
Magdalena MAROSZ, PH.D. \\ Archiwum Narodowe w Krakowie (National Archive in Krakow), ul. Sienna 1630-960, Kralów, Poland \\ e-mail:mmarosz@ank.gov.pl
}

Private Archives: Relationship with the State Archives

ABSTRACT

The relationships between the state archives and various types of private archives are of diverse character. The way they are handled depends, to a large extent, on the willingness to cooperate on the part of non-public institutions and their archives, but also on the real interest of the state archives in the problems of broadly understood private archives.

Key words: private archives, state archives, archival law

\section{Archivi privati: rapporti con gli archivi statali}

\section{SINTESI}

Le relazioni tra gli archivi di stato ed i vari tipi di archivi privati sono di caratteri diversi. Il modo in cui vengono gestiti dipende, in larga misura, dalla disponibilità a cooperare da parte degli enti non pubblici e dei rispettivi archivi, ma anche dall'interesse reale degli archivi statali nel capire i problemi degli archivi privati.

Parole chiave: archivi privati, archivi statali, legislazione archivistica

Zasebni arhivi: v odnosih z državnimi arhivi

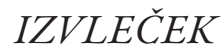

Odnosi med državnimi arhivi in različnimi tipi zasebnih arhivov so raznovrstni. Način njihovega delovanja je v veliki meri odvisen od pripravljenosti za sodelovanje $s$ strani nejavnih institucij in njihovih arhivov, pa tudi od resničnega interesa državnih arhivov pri problemu širšega razumevanja zasebnih arhivov.

Ključne besede: zasebni arhivi, državni arhivi, arhivsko pravo

Archiwa prywatne: relacje z archiwami państwowymi

\section{ABSTRAKT}

Relacje archiwów państwowych z różnego typu archiwami prywatnymi mają zróżnicowany charakter. To jak się układają zależy w dużej mierze od chęci do współpracy ze strony niepublicznych instytucji i działających w nich archiwów. Ale także od rzeczywistego zainteresowania archiwów państwowych problemami szeroko rozumianych archiwów prywatnych.

Słowa kluczowe: archiwa prywatne, archiwa państwowe, prawo archiwalne

\section{Non-state archival resource}

The Law on National Archival Resources and Archives, adopted in 1983, referring to the principles of archival law which existed in Poland before the World War II, introduced a legal concept of the institution of the national archival resource. Although this Law was adopted by the parliament (Sejm) in the communist era, during the Martial Law in Poland, it should be appreciated that through the introduc- 
tion of this legal provision archival materials started to be considered as public property and not merely a state owned entity. Namely, a broader concept, referring to the tradition of democratic states, was applied which was rarely used in the legislation of the communist states. A different issue is whether the later numerous changes and amendments to this Law, which have been introduced until today, paradoxically have not slightly distorted the original idea.

According to the Law, archival materials constituting the national archival resource are numerous and diverse records and documents, regardless of the manner of their creation and the type of carrier on which they were recorded, which are important as a source of information of a historical value about the activities, understood in a broader sense, of the Polish State, its organs and citizens. The national archival resource is divided into state and non-state archival resources.

The state archival resource is made up of the archival materials created as a result of the activities of the state and local government institutions, as well as political parties and political, social, occupational, economic and other non-state organizations; churches and religious associations; political, social and economic activists, scholars, artists and other people important for the development of political, cultural and economic life; families and houses that have had historical influence on the affairs of the state, on political, economic and social relationships - if these materials have become the property of the state as a result of purchase, donation or in a different way.

The non-state archival resource are the archival materials which are not state-owned. The non-state archival resource is divided into the registered, and non-registered one. The registered non-state archival resource consists of the materials created as a result of the activity of political parties, political organizations, cooperatives and other social organizations, churches and religious associations, and other nonstate organizations - which are their property. The non-registered resource comprises the materials of individuals and owned by these persons or their heirs.

Non-state institutions keeping the archival materials that are part of the non-state archival resource are obliged to register, store and secure them. Their archives may also keep a historical archival resource. The cooperation between these institutions and especially between their archives with the state archives is based on individual agreements concluded with the Minister of Culture and National Heritage.

The archival materials which constitute the non-state archival resource cannot be sold. When the institution creating and keeping such materials ceases its operations, they become state property, become a part of the state archival resource and should be transferred to one of the archives within the state archival network. The archival materials which constitute the non-state archival resource may, at any time, become the property of the State through the decisions of the competent bodies of the institutions that own them, they may also be transferred to the state archives as a deposit (Ustawa, 2018).

\section{State archival resource kept in private archives}

State archives should, to the same extent, supervise the archival materials constituting the state archival resources which are created and kept in public institutions, as well as the archival materials created in the institutions once belonging to the state or local government, which are currently kept in private archives. Following the political and property/proprietary changes that took place in Poland after 1989, the process of privatisation or transformation of state institutions into private companies meant that, along with all the assets, also the files of the former state institution were taken over by the new owner.

The state archives collect the information about where the documentation of state and local government institutions, which once, before they ceased their activity, were supervised by a given state archive, is currently kept. Unfortunately, they do not have such knowledge in relation to all liquidated or transformed state or local government institutions.

A considerable part of these archival materials, though they should have been transferred to the state archives a long time ago, still remains in the archives of the privatised institutions, even the ones transformed as early as in the 1990s. The problem has been serious on a national scale for many years. Unfortunately, there are still no legal grounds for the state archival service to make private companies account for the materials belonging to the state archival resource. 
However, in accordance with the legal regulations, state archives have the right and obligation to control the correctness of registering, keeping and securing the archival materials which belong to the state archival resource but are kept in the archives of private institutions. As a result of these controls, if necessary, post-audit recommendations may be issued, defining the steps that the institution keeping the files should undertake to better register and secure items in order to prepare them for transfer to the appropriate state archive.

The findings of the audits conducted so far confirm that, in many cases, the preparatory work, including the classification of documentation ${ }^{1}$ has been carried out incorrectly. The legal successors of state institutions are interested in leaving some or most of the archival materials at their place. The state archive may consent to the further keeping of the files belonging to the state archival resource in the archives of private institutions if they are still needed in the current operations of those companies.

Discontinuation of inspections usually negatively affects the conditions of preservation in an archive, which is a cause for concern, as there is a need for keeping personnel and payroll documentation of former employees in these companies.

Unfortunately, it is often impossible to enforce the implementation of the post-audit recommendations on private companies. Likewise, not everyone adheres to the provisions of archival law, which stipulates that it is obligatory to obtain the consent of the state archives for the destruction of non-archival documentation ${ }^{2}$ of former state institutions.

Often, the reason for the retention of archival materials by private institutions, transformed from the former state or local government institutions, is the reluctance to take up appropriate steps to prepare the files for transfer to the state archive. The authorities of these institutions believe that the procedure for the preparation of files for submission to the Archive is too expensive and time-consuming. Mostly, they do not have personnel adequately prepared for such duties.

It occurs that the owners of privatised institutions consider the documentation inherited from the former state-owned companies as their property, claiming that they had acquired the rights to the documentation as a result of the sale of the company. This applies mainly to the technical documentation of buildings, equipment and technological processes (Marosz, 2007).

\section{Social archives}

Social archives, as the name itself suggests, are created as a result of social, grass-root activities. Such archives are usually kept by various types of foundations, associations, local government institutions, and also by private individuals. Their goal is to collect, analyse, protect and share the documents, photographs, recordings and films relating to places, events, and people within the interest of the archive's organizer.

On the website of the social archive ${ }^{3}$ run by the KARTA Center Foundation, we can find a database of social archives from Poland and the Polish diaspora; currently (July 2018) the database includes 497 social archives operating in Poland and 66 Polish archives operating in 18 countries.

These archives collect various types of documentation. 80 percent of them collect photographs, they also store personal documents, other iconographic materials, and documents of social life (Ziętal, 2015).

The institutions that run social archives are non-governmental organizations (59\% of the archives), local government institutions (31\%), private individuals (8\%), corporations and trade unions (2\%). Among the non-governmental organizations, $75 \%$ are associations and the remaining $25 \%$ - foundations (Ziętal, 2017).

\footnotetext{
1. Assessment of the value of documentation, as a result of which the documentation is assigned to a given archival category. It can be classified as archival material stored perpetually, having the value of an archival source, or as archival documentation with a temporary storage period, resulting from specific regulations and usefulness for practical purposes of a given institution.

2. Selection and handing over for destruction of this part of non-archived documentation whose storage period, in accordance with applicable regulations, has expired and which has been considered unsuitable for the practical purposes of the institution.

3. www. archiwa.org (accessed 13.07.2018).
} 
The institutions that run social archives usually undertake broadly understood cultural and educational activities, popularising history and cultural heritage, conducting research, engaging in educational, publishing or artistic activities. They acquire archival materials in a variety of ways and collect them from various perspectives, depending on the primary purpose of the institution which organises a given archive.

The most important field of interest for social archives are local topics (such collections were gathered by $67 \%$ of these archives), followed by social history (15\%), history of culture (11\%), war topics (10\%), history of individuals (6\%), history of social movements (6\%), history of the anti-communist opposition (4\%), history of music (2.5\%), history of education (2\%). Other topics occur individually. About $25 \%$ of social archives collect audio recordings that are sources of oral history, and $20 \%$ collect video recordings (Ziętal, 2017). Naturally, one archive may collect archival materials related to more than one issue.

From the point of view of the state archival service, social archives collect the non-state, registered archival resources, constituting an essential part of the national archival resource. For this reason, they are also protected legally, though the concept of social archives does not appear in archival law itself. Until 2007, in the archival law, there was a provision concerning the obligation of the state archives to keep a register of non-state archival resource. This register provided extremely valuable information, including statistical information, on the quantity and distribution of resources in private archives. It is regrettable that, when archival law was being amended, this provision was removed. On the other hand, another provision was introduced referring to the compulsory takeover of archival materials by the state archives in the event of there arising a danger of loss, destruction or damage and in the case of the threat of export without the required consent of the Head Director of the State Archives (Ustawa, 2018).

In 2015, when a further amendment to the Law took place, an article was added giving the Head Director of the State Archives the possibility of outsourcing the realisation of public tasks in the field of recording, storage, analysing, sharing and securing archival materials from registered non-state archival resource (Ustawa, 2018). It provides the opportunity of giving financial support from the state archival service to private institutions running their own archives.

Social archives perform an extremely important and difficult to overestimate role in securing and protecting the part of archival materials collected by private individuals and institutions. It is probably thanks to social archives that a significant part of these materials will be preserved for future generations. This function is recognised and appreciated by the state archives.

Undoubtedly, the establishment in 2002 of the Social Archives Council at the Head Directorship of the State Archives was a much welcome initiative. The Council remit was to deal with the development of the principles of state support for social archives and of the collection of information about them and their resources. Unfortunately the Council, in a short time, practically ceased to function (Kostankiewicz, 2017).

An equally untapped opportunity, this time in the field of the popularisation of private archival resource, is the bookmark Valuable Documents in the possession of individuals and organizations ${ }^{4}$ on the homepage of the Head Office. Contrary to the title, it gives merely brief information on how valuable private collections can be, and that it is worth taking care of appropriate storage.

On the other hand, an important and quite well-functioning way of cooperation is placing the information about the resources of private archives in the information system on archival resources run by the state archival network. Some social archives, on a voluntary basis have transferred data on their resources for inclusion in the archival website szukajwarchiwach which presents the descriptions and scans of archival materials kept in state archives and non-public archives. The archives which place their data on this website also use the ZOSiA system, prepared for the needs of the state archives and used to register archival materials.

For now, unfortunately, private archives, including social ones, are very modestly represented on this website, but hopefully, over time, more and more institutions will present information about their resources.

4. www.archiwa.gov.pl/pl/dla-uzytkownikow/cenne-dokumenty-w-posiadaniu-os\%C3\%B3b-i-organizacji (accessed 29.06.2018). 


\section{Church archives}

A special group of archives which keep a non-state, registered archival resource are church archives. Special, because of their extremely valuable historical resource, oftentimes dating back to the early Middle Ages.

Church archives, both diocesan and monastic, are not only the earliest archival institutions in Poland but also those for which legal regulations concerning their functioning were first introduced. Let us only mention here the statutes of Archbishop Jakub Świnka from 1285, obliging church authorities to carefully keep all documents relating to foundations and donations given to churches. Synodal legislation also dealt with archival matters. Individual monasteries preserved and conserved their documents as well.

Nowadays, the current Code of Canon Law, issued in 1983 although rather briefly, defines the principles according to which the archives of church institutions should be organized. Also, the contemporary diocesan synods deal with archival matters. Among the synodal documentation of some of the dioceses, we can find the statutes of central diocesan archives, basically concerning historical resources. In these documents, there can be seen more and more detailed regulations, especially regarding the archives of the diocesan curia. Of course, each document is an independent and separate whole. However, while appreciating the efforts made to regulate the issues of church archival matters, we should also draw attention to certain shortcomings. First of all, regulations regarding archival matters were introduced only in five dioceses. Moreover, the records are not always precisely formulated and do not provide references to the provisions within Polish archival law, in particular, the Law on National Archival Resources and Archives. There is a lack of clear regulations regarding the supervision of the archives subordinate to the Bishop Ordinary, and thus over the parish archives as well as church institutions and associations operating in a given diocese. (Różanski, 2016).

Certainly, the issue of supervision over the proper functioning of the archives should be more strictly regulated in the provisions addressed to church archives. These archives, like all Polish archives, have suffered considerable losses throughout history, especially during the $19^{\text {th }}$-century dissolution of monasteries, during the partitions of Poland and at times of the two world wars. However, it must be admitted that the losses also have resulted, to some extent, from the lack of adequate security and proper protection of the resource, and sometimes even from the carelessness of people who were to take care of them.

In fact, it was only in the second half of the $20^{\text {th }}$ century that the people responsible for church archives, drawing also from the experience of state archives, began to appreciate the importance of archival materials and attach importance to their proper analysis and preservation. The first impulse here was the decision of the Primate of Poland, Cardinal Stefan Wyszyński who, in 1959, in connection with the approaching $1000^{\text {th }}$ anniversary of the Baptism of Poland, recommended setting in order and registering all church archives in Poland. From 1960, special training for church archivists has been conducted at the Catholic University of Lublin.

A significant role in promoting archival standards is played by the Association of Church Archivist, established in 2004, which in its assumptions refers to the tradition of the Association of Polish Archivists.

The relationships between church archives and the state archival service are defined in the archival law and are similar to the relationships with other non-public archives. However, an imprecise term is used in this law. It consistently uses the term 'churches and religious associations', which is not correct from the point of view of the Law on Guarantees of Freedom of Conscience and Religion 5 from 1989, which introduces the concept of 'churches and other religious associations'. Thus, the term 'religious association' has a broader meaning and concerns those subjects which have a regulated relationship with the state and have been entered into the register of churches and other religious organisations kept by the minister responsible for religious denominations ${ }^{6}$ (Różański, 2017).

It is not only archival law that concerns the matters of church archives and relationships between the state, individual churches and other religious associations. Also denominational legislation, among

$\overline{\text { 5. Ustawa z dnia } 17}$ maja 1989 r. o gwarancjach wolności sumienia i wyznania, Dz.U. 2017, poz. 1153.

6. Currently it is the Minister of the Interior and Administration. 
the indicated areas of cooperation with the state, mentions the issues related to the functioning of church archives. The rights of church institutions to possess, share and preserve archival materials follow from this legislation. The Law on the Relationship of the State to the Catholic Church in the Republic of Poland of 1989 stipulated that 'church legal persons have the right to establish and possess archives and museums.' Similar provisions can be found in corresponding legal acts concerning other churches whose relations with the state are regulated by the law (Różanski, 2017).

Church archives, due to the extremely valuable materials they contain, which often have the value of primary source materials not only for the history of the church in Poland, but generally carrying information about the history, culture, and the development of the Polish State, should remain in the sphere of special interest of the state archival service. This interest, however, should respect the full autonomy and distinct character of these archives and the institutions whose files they keep. It seems that the areas where the state archives could be helpful, due to their well-established experience, are the archival methodology of analysis and registering of collections as well as conservation and preservation. Similarly, the information system on archival resources, run by the state archival network, could be a good field for cooperation. It seems, however, that both the state and church archival services still need time to work out a mutually satisfactory model of cooperation.

\section{References}

Kostankiewicz, M. (2017). Polityka państwa wobec archiwów spotecznych w latach 2005-16, [in:] Archiwistyka społeczna. Diagnoza i wyzwania, ed. A. Jóźwik, K. Ziętal, Warszawa 2017, pp. 33-61.

Marosz, M. (2007). Protection of State Archival Materials Kept in Private Archives, Atlanti, Vol. 17. N. 1-2, 2007, pp. 203-207.

Różański, M. (2017). Status materiatów archiwalnych przechowywanych $w$ historycznych archiwach kościelnych, Kościół i Prawo, Vol. 6 (19), N. 2, 2017, pp. 251-262.

Różański, M. (2016). Statuty archiwów historycznych $w$ dokumentacji synodalnej synodów diecezjalnych $w$ Polsce po wprowadzeniu nowego kodeksu prawa kanonicznego, Łódzkie Studia Teologiczne, Vol. 25, N, 2, 2016, pp. 117-125.

Ustawa $z 14$ lipca 1983 o narodowym zasobie archiwalnym i archiwach. Tekst jednolity, Dz.U. 2018, poz. 217.

Ziętal, K. (2015). Archiwa spoteczne na świecie i ich relacje z państwem. Budowanie polskiego modelu, [in:] Archiwa społeczne. Modele współpracy z państwem, ed. K. Ziętal, Warszawa 2015, pp. 13-31.

Ziętal, K. (2017). Archiwa spoteczne w Polsce - prezentacja i analiza wyników badań, [in:] Archiwistyka społeczna. Diagnoza i wyzwania, ed. A. Jóźwik, K. Ziętal, Warszawa 2017, pp. 14-32.

\section{SUMMARY}

Private archives differ not only in the type and importance of the documents kept. They also differ in their history, the history of the resource kept, professional preparation of the employees, care taken for the condition and security of the stored documents. It is not surprising, then, that their relationships with the state archival service are also varied. It seems that of fundamental importance here is the perception of state archives as a kind of guardian of the national archival resource, sometimes understood as a threat to the ownership of a given resource. However, better and better understanding of the provisions of the archival law allows for the correction of mutual relations. This is particularly visible in the cooperation in the field of sharing registering aids and resource security.

Typology: 1.01 Original scientific article

Submission date: 26.07 .2018

Acceptance date: 08.08.2018

$\overline{\text { 7. Ustawa z dnia } 17}$ maja 1989 r. o stosunku Państwa do Kościoła Katolickiego w Rzeczypospolitej Polskiej, Dz.U. 2013 , poz. 1169 z późn. zm. 